\title{
THE EFFECT OF FERTILIZATION ON THE YIELD COMPONENTS OF WINTER WHEAT
}

\author{
Péter Jakab, Ágnes Jusztin, Anita Baranyi, Margit Szél Hódiné \\ University of Szeged, Faculty of Agriculture, Hódmezővásárhely, Hungary \\ jakab.peter@mgk.u-szeged.hu
}

\begin{abstract}
We investigated the effect of fertilization on the yield components of winter wheat in the crop-year 2016/2017. The experiment was set up in three replications on the area of the SZTE Tangazdaság Ltd. in Hódmezővásárhely. The soil was meadow soil. The forecrop was sunflower. Six fertilizer treatments were used besides the control: N80PK30, N100PK30, N130PK30, N150PK30, N170PK0 and N170PK50 kg/ha active ingredients. Experimental results were processed using single factor ANOVA.

The number of spikes $/ \mathrm{m}^{2}$ was 564.67 in the control treatment. In the N100PK30 and N130PK30 treatments we measured significantly higher values of 567.67 and 677.33 spikes $/ \mathrm{m}^{2}$. The number of kernels per spike was 36.5 in the non-fertilized parcels. We reached the highest value of 43.77 kernels in the N130PK30 treatment. The difference was not significant. The thousand kernel weight changed slightly due to the fertilization. We measured $31.08 \mathrm{~g}$ in the control treatment. We got the maximum value of $32.71 \mathrm{~g}$ in the N130PK30 treatment. The difference was not statistically justified. Our scientific results showed, that the N130PK30 kg/ha fertilizer level was the optimum for the winter wheat in 2016/2017.
\end{abstract}

Keywords: winter wheat, fertilization, yield components, thousand kernel weight, number of spikes

\section{INTRODUCTION}

The winter wheat has an important role in Hungarian crop production. The sowing area of wheat varies between 1.0-1.0 million ha. In Hungary, the average yield of winter wheat was 5.0-5.5 t/ha in the 1980's but nowadays the average yield varies between 3.0-5.0 $\mathrm{t} / \mathrm{ha}$ depending on the climatic factors of crop-year (PEPÓ, 2007).

In sustainable cereal production, nutrient supply, fertilization is a key agrotechnical element (OEHL ET AL., 2004; KELLER ET AL., 2012).

In a favourable year, after good fore-crop the winter wheat reached the maximum yield in a N80PK30 treatment. The fertilization had different effects on the examined generative factors. The thousand seed weight did not change significantly, but the change of length of spike and number of spiklets under the influence of fertilization was significant (JAKAB ET AL., 2017).

Beside the yield amount, the nutrient supply had great effect on the different yield components of winter wheat. The higher $\mathrm{N}$ dosage increased the number of spikes and the number of grains per spike (RUZSÁNYI, 1985).

Macroelements play an important role in the formation of yield components of winter wheat (the number of shoots, the number of ears, the number of spikelets) (RAGASITS, 1998; PETRÓCZI ET AL., 2005; KRISTÓ ET AL., 2007, 2008).

There is a significant correlation between $\mathrm{N}$ supply and thousand seed weight. Fertilization had a significant effect on the length of spike, weight of spike and grain number of spike (LÖNHARDNÉ ET AL., 1995; JAKAB ET AL., 2016). 


\section{MATERIAL AND METHOD}

The experiment was set up in three replications on the area of the SZTE Tangazdaság Ltd. The soil was meadow soil, which was nearly neutral (Table 1).

Table 1. Main properties of the experimental field area

\begin{tabular}{|c|c|c|c|c|}
\hline $\begin{array}{c}\mathbf{p H} \\
\mathbf{( K C L})\end{array}$ & $\begin{array}{c}\mathbf{P}_{\mathbf{2}} \mathbf{O}_{\mathbf{5}} \\
(\mathbf{m g} / \mathbf{k g})\end{array}$ & $\begin{array}{c}\mathbf{K}_{\mathbf{2}} \mathbf{O} \\
(\mathbf{m g} / \mathbf{k g})\end{array}$ & $\begin{array}{c}\text { Humus } \\
(\mathbf{\%})\end{array}$ & $\begin{array}{c}\text { Soil plasticity } \\
\text { value }\left(\mathbf{K}_{\mathbf{A}}\right)\end{array}$ \\
\hline 7.16 & 335 & 619 & 3.38 & 48 \\
\hline
\end{tabular}

Source: HL-LAB Ltd., 2016

The year 2016-2017 was unfavourable for winter wheat production. The amount of precipitation in the vegetative period of winter wheat was lower by $80.2 \mathrm{~mm}$ than the 50 years average. The distribution of precipitation was unfavourable (Table 2).

The experiment was set in three replications, organised as a random block in 2016. Beside the control, we applied six fertilizer treatments: N80PK30, N100PK30, N130PK30, N150PK30, N170PK0, N170PK50 kg/ha active ingredients. The forecrop was sunflower. The variety was Lucullus. The experimental data were analysed by single factor ANOVA.

Table 2. The distribution of precipitation in the vegetative period of winter wheat in 2016-2017

\begin{tabular}{|c||c||c||c||}
\hline Month & Rainfall $\mathbf{( m m )}$ & $\begin{array}{c}\text { 50 years average } \\
\text { rainfall } \\
\mathbf{( m m )}\end{array}$ & $\begin{array}{c}\text { Difference } \\
\mathbf{( m m})\end{array}$ \\
\hline \hline October & 88.0 & 34.7 & 53.3 \\
\hline November & 50.0 & 41.1 & 8.9 \\
\hline December & 2.0 & 43.0 & -41.0 \\
\hline January & 20.0 & 30.6 & -10.6 \\
\hline February & 24.0 & 30.1 & -6.1 \\
\hline March & 11.0 & 29.8 & -18.8 \\
\hline April & 43.0 & 39.9 & 3.1 \\
\hline May & 71.0 & 58.0 & -27.3 \\
\hline June & 48.0 & 75.3 & -54.7 \\
\hline July & 4.0 & 58.7 & $\mathbf{- 8 0 . 2}$ \\
\hline Total amount of \\
rainfall (mm)
\end{tabular}

Source: SZTE Tangazdaság Ltd.

\section{RESULTS}

We investigated the effect of fertilization on the yield components of winter wheat (the number of spikes $/ \mathrm{m}^{2}$, number of kernels per spike, and thousand kernel weight). Fertilization had different effects on the yield components of winter wheat. The number of spikes $/ \mathrm{m}^{2}$ was 564.67 in the control treatment. Under the influence of fertilization the values increased. The maximum values were 657.67 and 677.33 pieces in the N100PK30 and N130PK30 kg/ha treatments, respectively. These results were significantly higher compared to the control (Figure 1). 


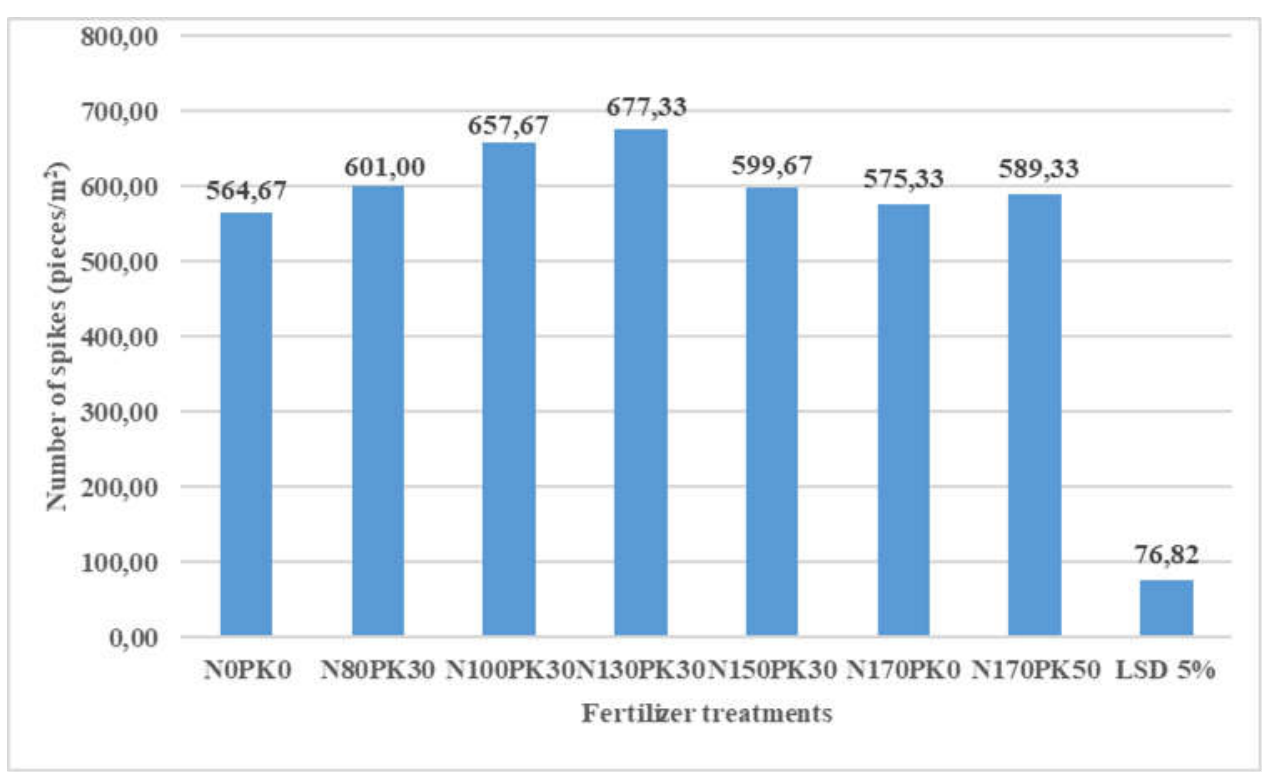

Figure 1. The effect of fertilization on the number of spikes $/ \mathrm{m}^{2}$ of winter wheat

The thousand kernel weight is highly dependent on the genetical background of the variety. However, the ecological and agrotechnical factors are able to influence this parameter. Among the agrotechnical factors, fertilization had the highest effect on this parameter. Our study proved that the thousand kernel weight is strongly dependent on the genotype. The thousand kernel weight was $31.8 \mathrm{~g}$ in the control treatment. Fertilization slightly increased this parameter, its effect was not significant. We measured the maximum value, $32.71 \mathrm{~g}$, in the N130PK30 treatment (Figure 2).

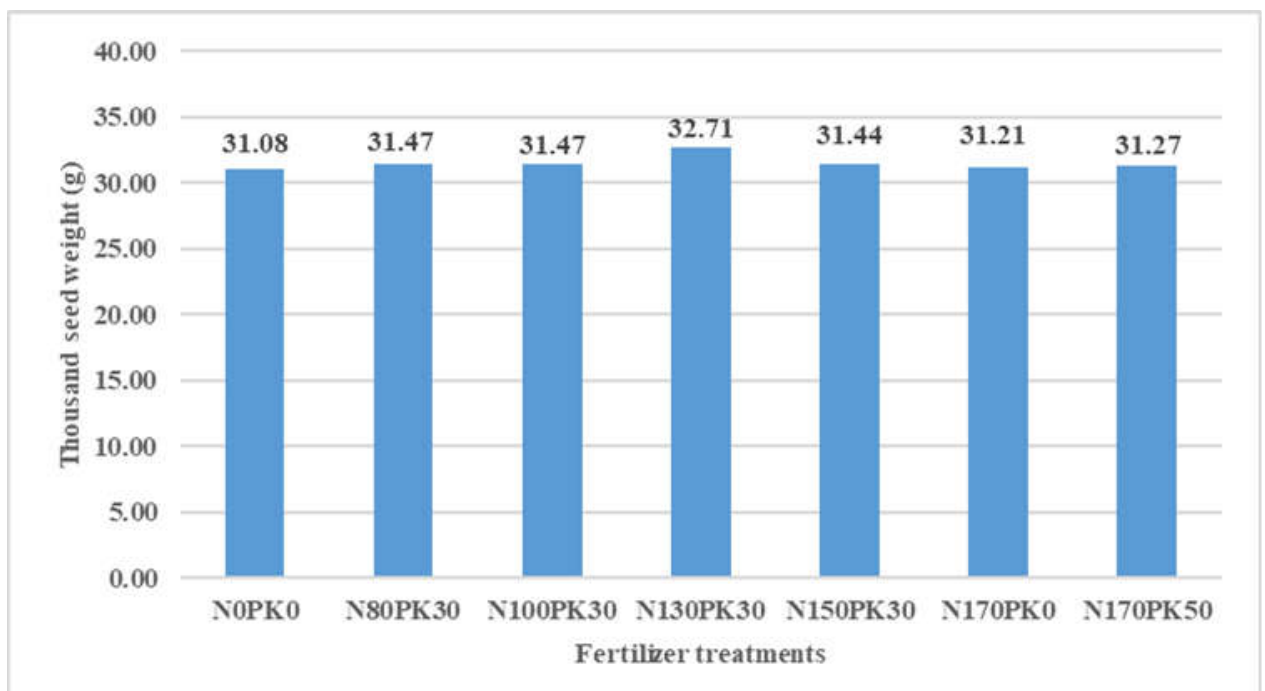

Figure 2. The effect of fertilization on the thousand kernel weight of winter wheat

The number of kernels per spike is also an important yield component. The fertilization can increase this yield component. In our experiment, the number of kernels per spike in the control treatment was the minimum, 36.50 pieces. Under the influence of fertilization, the values increased (40.8-43.77 pieces). The maximum value, 43.77 pieces was measured in the N130PK30 treatment, but the difference compared to the control was not statistically justified (Figure 3). 


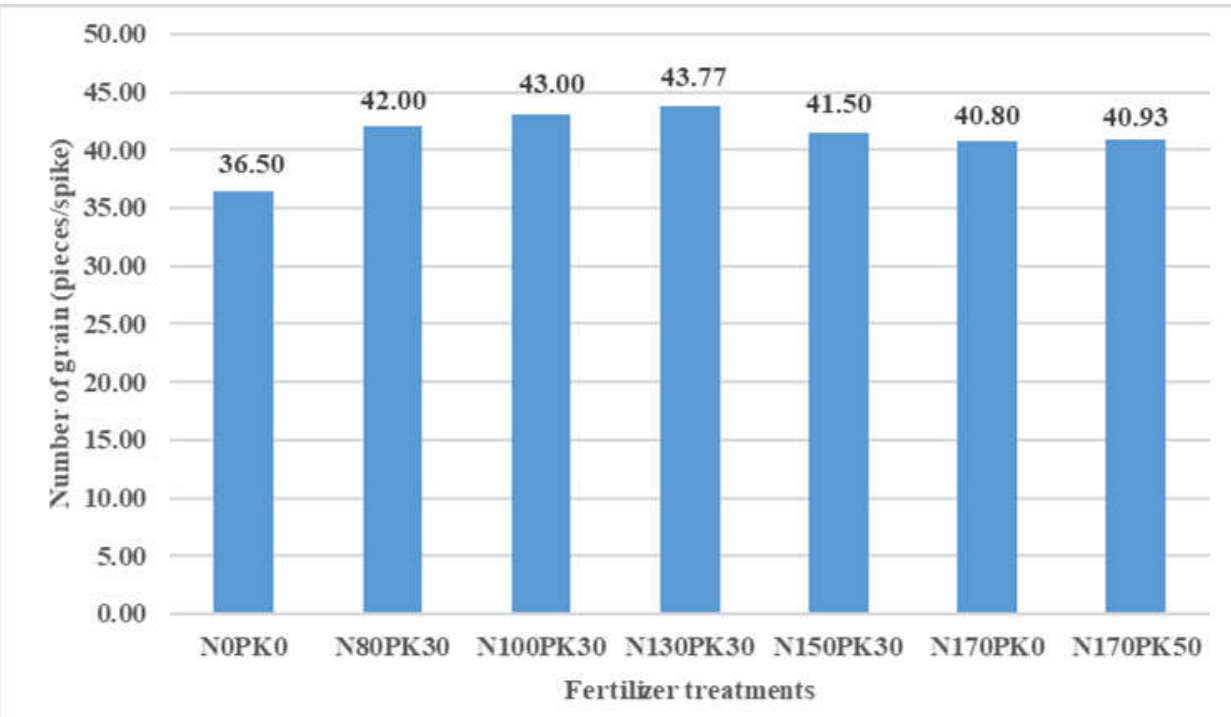

Figure 3. The effect of fertilization on the number kernels per spike of winter wheat

\section{CONCLUSIONS}

Nutrient supply has an important role in wheat production. Winter wheat is one of the best fertilizer-responding field crop. Weather conditions (mainly the amount and distribution pf rainfall) can modify the yield components of winter wheat. Fertilization had different effects on the examined generative factors. The thousand kernel weight and number of kernels per spike did not change significantly, but the change of the number of spikes $/ \mathrm{m}^{2}$ under the influence of fertilization was significant. We can conclude that concerning the yield components the moderate fertilizer dosage of N130PK30 was the most favourable fertilizer dosage in our experiment.

\section{REFERENCES}

JAKAB, P., FESTŐ, D., KOMAREK, L. (2016): A mütrágyázás hatása az őszi búza termésére és termésképző elemeire. In: Futó Zoltán (szerk.) Kihívások a mai modern mezőgazdaságban. Konferencia helye, ideje: Szarvas, Magyarország, 2016.11.24 Szarvas. Szent István Egyetemi Kiadó. 68-73. (ISBN: 978-963-269-594-5)

JaKAB, P., FestÖ, D., Zoltán, G., Komarek, L. (2017): Examination of fertilization of winter wheat on meadow chernozem soil. Research Journal of Agricultural Science 49(1): 127-134.

Keller, M., Oberson, A., Annaheim, K.E., Tamburini, F., Maeder, P., Mayer, J., Frossard, E., BuENEMANN, E.K. (2012): Phosphorus forms and enzymatic hydrolyzability of organic phosphorus in soils after 30 years of organic and conventional farming. Journal of Plant Nutrition and Soil Science 175(3): 385-393.

Kristó, I., SzARvas, A., SzARVAS, M., Petróczi, I. M. (2007): A tápanyagellátás hatása az öszi búza fejlödésére. Agrár- és Vidékfejlesztési Szemle 2(2): 119-124

Kristó, I., HegedÜs, Sz., Petróczi, I. M. (2008): Investigation of the development of winter wheat under different fertilizer rates. Cereal Research Communications 36. Suppl.:1183-1186. 
LÖNHARDNÉ, B. É., NÉMETH, I., RAGASITS, I. (1995): N és P trágyázás hatása a búza generatív fejlödésére. Növénytermelés 44(2): 171-177.

Oehl, F., Frossard, E., Fliessbach, A., Dubois, D., Oberson, A. (2004): Basal organic phosphorus mineralization in soils under different farming systems. Soil Biology and Biochemistry 36: 667-675.

PEPÓ, P. (2007): The role of fertilization and genotype in sustainable winter wheat (Triticum aestivum L.) production. Cereal Research Communications 35(2): 917-920.

Petróczi, I. M., GyURIS, K., KRIstó, I. (2005): P és K trágyázás hatása az őszi búza terméselemeire mütrágyázási tartamkísérletben. In: Wellmann Oszkár Tudományos Tanácskozás, Hódmezővásárhely. 1.

RAGASITS, I. (1998): A búza terméselemeinek változása a mütrágyázás hatására. Gyakorlati Agrofórum 9(10): 29-31.

RUZSÁNYI, L. (1985): A mütrágyázás hatása az őszi búza termésére öntözött és nem öntözött kísérletben. [In: Bajai J.,- Koltay Á. (ed.): Búzatermesztési Kísérletek. 19701980.] Akadémiai Kiadó 